\title{
Diversity of soil organic carbon and water characteristics under different vegetation types in northern Bengkulu, Indonesia
}

\author{
BANDI HERMAWAN ${ }^{1, \vartheta}$, HERY SUHARTOYO ${ }^{2, \bullet \bullet}$, BAMBANG SULISTYO ${ }^{1}$, \\ BAMBANG GONGGO MURCITRO ${ }^{1}$, WELLY HERMAN ${ }^{1}$ \\ ${ }^{1}$ Soil Science Program, Faculty of Agriculture, Universitas Bengkulu. Jl. WR. Supratman, Kandang Limun, Bengkulu City 38371, Bengkulu, Indonesia. \\ Tel./fax.: +62-736-21290, "email: bhermawan@unib.ac.id \\ ${ }^{2}$ Department of Forestry, Faculty of Agriculture, Universitas Bengkulu. Jl. WR. Supratman, Kandang Limun, Bengkulu City 38371, Bengkulu, Indonesia. \\ Tel./fax.: +62-736-21290, "`email: hery_suhartoyo@yahoo.com
}

Manuscript received: 10 December 2019. Revision accepted: 4 April 2020.

\begin{abstract}
Hermawan B, Suhartoyo H, Sulistyo B, Murcitro BG, Herman W. 2020. Diversity of soil organic carbon and water characteristics under different vegetation types in northern Bengkulu, Indonesia. Biodiversitas 21: 1793-1799. Organic carbon and water characteristics are important soil properties that can easily degrade following the conversion of forest to cultivation land, but their levels of degradation depend on successive vegetation types after deforestation. The research aimed to evaluate the spatial diversity of soil organic carbon (SOC) and water characteristics on sites with annual and cash crops, as well as natural vegetation types. Forty-two undisturbed and disturbed soil samples were collected at 0-10 and 10-20 cm depths from plantation areas (rubber and oil palm), rice fields, shrub land, and grassland in Mukomuko, North Bengkulu, and Central Bengkulu Regencies of Bengkulu Province, Indonesia. Vegetation types were observed, and soil water characteristics were determined using a pressure plate apparatus unit from undisturbed soil samples, while SOC and particle-size distribution were analyzed from disturbed soil samples. The uppermost $10 \mathrm{~cm}$ soil layers were dominated by organic-C intervals of more than $3.0 \%$ while the $10-20 \mathrm{~cm}$ depths had intervals of less than $3.0 \%$. Soils under oil palm and rice production had higher SOC of above $6.0 \%$ and water availability at the field capacity of $0.4-0.6 \mathrm{~g} \mathrm{~g}^{-1}$, particularly at $0-10 \mathrm{~cm}$ depths, while those under rubber and grass had a lower status of measured variables, particularly at $10-20 \mathrm{~cm}$ depth. There was a strong relationship $\left(\mathrm{R}^{2}=0.63\right)$ between the soil organic carbon and water availability among study soils, suggesting the possibility to predict potential soil water deficits from organic matter status.
\end{abstract}

Keywords: Forest conservation, intensive cultivation, land use, soil deterioration

\section{INTRODUCTION}

In the last two decades, in northern parts of Bengkulu Province, Indonesia, there have been significant land-use changes leading to the massive addition of plantation areas especially rubber and oil palm plantations that may lead to serious soil degradation issue (Mujiono et al. 2017). In North Bengkulu Regency, the loss of forest area during this period has been 80,038 ha, and at the same time, the plantations by people and private companies have increased by 86,466 ha. Along with decreases in root biomass and nutrient stocks, soil organic carbon (SOC) and water characteristics are two important soil properties that can easily degrade following the conversion of forest to cultivation land (Pransiska et al. 2016). The degree of land degradation depends on pedogenesis, climatic conditions, and successive vegetation types that have grown after deforestation. Perennial crop trees such as rubber and oil palm may deposit SOC on the soil surface from the decomposition processes of falling leaves and branches but leaving the subsurface with less input of organic materials. Fast-growing cash crops, on the other hand, usually have an abundance of underground root biomass and carbon deposits when followed with the addition of organic materials. For example, intensive application of farmyard manure to the mono-cropping of lowland rice improved soil hydro-physical properties such as SOC and moisture retention capacity. Therefore, this may be an alternative solution to prevent soil deterioration and sustain land productivity under intensive cultivation practices (Saha and Mishra 2009).

Significant increases in critical land-use changes in areas of Bengkulu Watershed have occurred in the last ten years, according to both satellite image analyses and field observations. The areas of critical land-use changes in Bengkulu Watershed (which are usually indicated by soils with decreasing organic matter content) increased from 240,824 ha in 1990 to 306,202 ha in $2005,1,114,189$ ha in 2015, and 1,211,084 ha in 2016 (Supriyono 2018). Prior to deforestation, forestlands in North Bengkulu were dominated by soils with high SOC of 6.40 to $11.65 \%$ as reported by Centre for Soil and Agroclimate Research (1990). Changes to degraded land dominated by soils low in organic matter content may result in severe erosion, since soil organic materials increase water repellency and reduce detachable particles of surface soils when subject to running water (Barton and Colmer 2011). Our previous study showed that significant soil deterioration in North Bengkulu had occurred about two years after the conversions of forestlands to cultivated lands (Hermawan et al. 1997). On the other hand, when soil erosion occurs, the loss of soil material may also include loss of organic 
compounds such as SOC carbon (Mey et al. 2015). Rusdiana and Lubis (2012) reported that decrease in the carbon stock of secondary forest land had strong correlations with soil fertility, as shown by soil acidity and nutrient availability. Soil aggregate stability, soil compaction, and soil water movement were other soil properties that changed significantly when the forest areas were converted for conventional agricultural activities without prospecting soil conservation techniques (Endriani 2011).

Soil organic matter (OM) plays very important roles in improving water availability to plants because water precipitation that falls to surface soils will infiltrate to the soil profile and be absorbed by soil particles with high contents of organic material. As reported by Karyati et al. (2018), improving OC content of eroded soils was also beneficial in increasing the survival of tree plants and cash crops under agroforestry practices. Therefore, there is a need for information on the diversity of SOC - as a major component of $\mathrm{OM}$ - in relation to vegetation types growing in the undulating northern regions of Bengkulu. Our study aimed to evaluate the spatial diversity of SOC and water characteristics for soils grown with annual and cash crops, as well as natural vegetation types, in northern regions of Bengkulu. We assumed that the land covered with different vegetation types would have different SOC content and water characteristics in the study areas.

\section{MATERIALS AND METHODS}

\section{Study areas}

The study was conducted during the dry season of 2018 in northern parts of Bengkulu Province, Indonesia. Locations of the study were in districts of Mukomuko, North Bengkulu, and Central Bengkulu (Figure 1). The map of study regions was produced using ArcGIS version 10.3 from the shapefile of Land Unit and Soil Map of The Bengkulu Province, Centre for Soil and Agroclimate Research, Bogor. The area of regencies bordered to West Sumatra Province in the north, Bengkulu City and Seluma Regency in the south, Indonesian Ocean in the west, and Bukit Barisan in the east. The locations laid on the north-to-south direction at the west coast of Sumatra ranged from $20 \mathrm{~m}$ in the coastal regions to $200 \mathrm{~m}$ above sea levels towards Bukit Barisan high land. The northern regions of Bengkulu have dominated three soil classes (i.e., Entisols and Histosols at the west coast and Inceptisols at the eastern regions). In the last three decades, some parts of the study area were converted from secondary forest to cultivation land, including rubber and oil palm plantations. Twenty-one locations were used for soil sampling covering seven sites of Mukomuko (MM1-MM7), North Bengkulu (NB1-NB7), and Central Bengkulu Regencies (CB1-CB7), respectively.

Distributions of vegetation types in the study areas, as well as geographical positions and the altitudes of soil sampling sites, are presented in Table 1. Most of the study sites in all regencies were covered by mature oil palm at the altitudes of about 20-105 m above sea level and by rubber trees at the higher altitudes. Both oil palm and rubber plantations occupied about $50 \%$ and $25 \%$ of sampling sites, respectively, followed by paddy fields, shrubs, mango, and grass at about $25 \%$ in total. These vegetation types represented most cultivated plants after the conversion of secondary forest in agricultural land in Bengkulu Province. Oil palm and rubber plantations were two main commodities in the agricultural sector that generated economic incomes for people and regions in Bengkulu Province (BPS 2016).

The study areas had a very high diversity in the land characteristics within and among vegetation types, as shown in Table 2. The study sites laid in the range of the lowland west coast areas at about $20 \mathrm{~m}$ above sea level and a medium country site at $201 \mathrm{~m}$ above sea level. Soil texture classes in the study region ranged from clay to loamy sand, as found under the lowland sites of grass and oil palm, respectively. Soil compaction also varied widely, as indicated by the bulk density values from 0.24 for a peaty soil to $1.38 \mathrm{~g} . \mathrm{cm}^{-3}$ for a mineral soil, as found under oil palm plantations. Information about the diversity in land characteristics of the study area would be important to explain non-vegetation effects regarding organic carbon and water variability of studied soils.

\section{Procedures}

\section{Soil sampling}

The spatial distribution of soil sampling points was determined according to the variability of vegetation types and land units in the study area. Collected soil samples were assumed to provide not only information about the soil from which the samples were drawn, but also implied the parts of soil population under each vegetation type that were not measured. Forty-two undisturbed and disturbed soil samples were collected purposively at 0-10 and 10-20 $\mathrm{cm}$ depths from plantation areas (rubber and oil palm), rice fields, shrubland, and grassland in Mukomuko, North Bengkulu, and Central Bengkulu Regencies of Bengkulu Province. Undisturbed soil samples were taken using cylindrical cores of 7.2 and $7.5 \mathrm{~cm}$ in height and diameter, respectively; the cores were then covered at the top and bottom sides with plastic for laboratory analysis. At the same time, disturbed soils were taken from the undisturbed sampling points and put into plastic bags for texture and organic carbon analyses in the laboratory.

\section{Parameters}

Vegetation types growing in each location were observed and the density of canopy and percentage of surface coverage were determined. In this study, these vegetation variables acted as dependent variables responsible for spatial diversity of SOC and available water content. Soil water characteristics were determined from undisturbed soil samples using a pressure plate apparatus unit applied with a 1-bar pressure to release water from soil samples. When the pressure at the plate and soils reached equilibrium as indicated when the water stopped dripping from the soil samples, the samples were weighted to calculate the amount of water remaining in pores less than $20 \mu \mathrm{m}$ in diameter, known as soil water at the field capacity condition. Soil organic carbon and particle-size distribution were analyzed from disturbed soil samples using the Walkley and Black method and hydrometer technique (Klute 1986), respectively. 


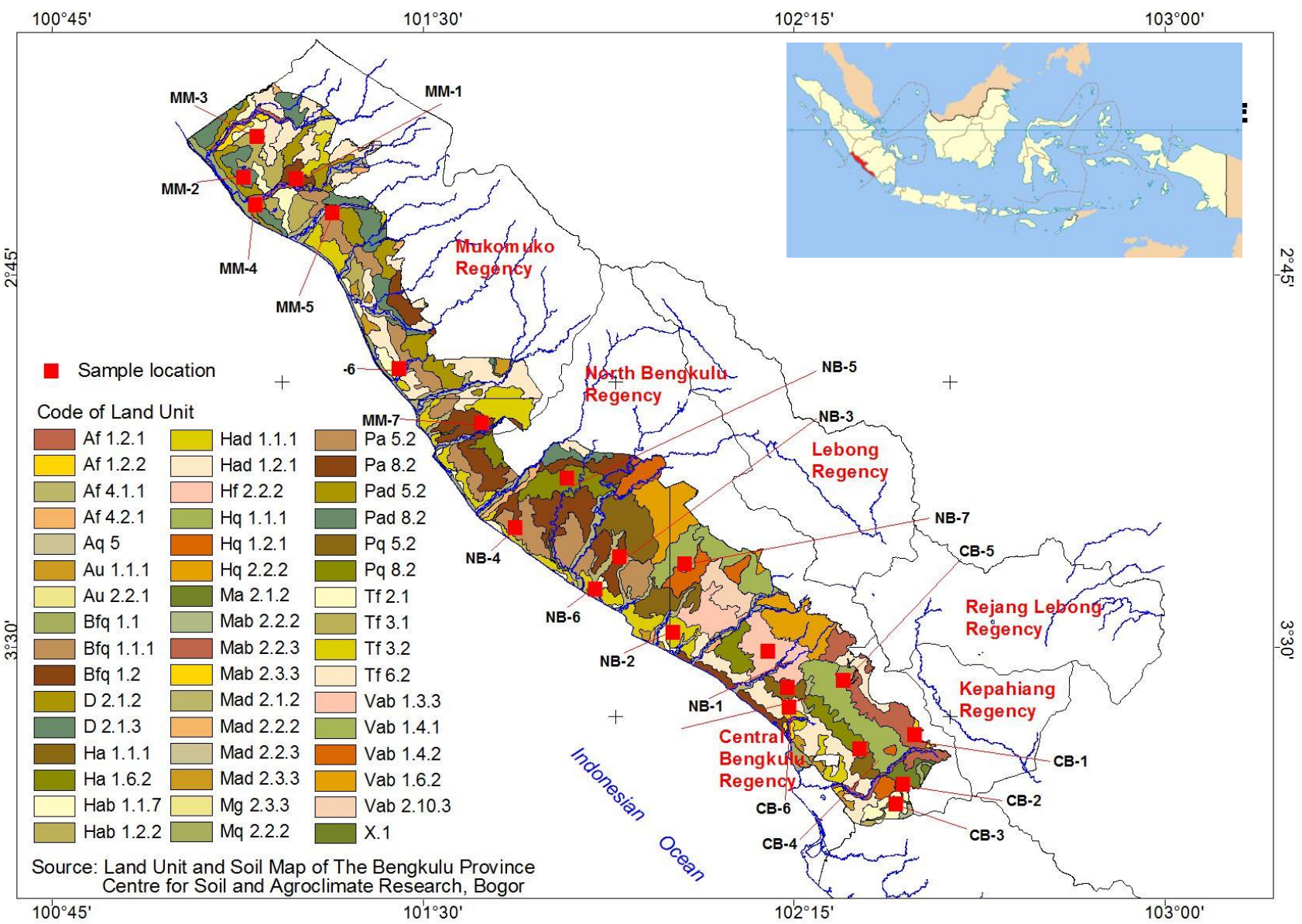

Figure 1. Location of study area covering three regencies in northern parts of Bengkulu Province, Indonesia

Table 1. Types of vegetation at study sites

\begin{tabular}{|c|c|c|c|c|}
\hline Regency & Sampling site* & Geographical positions & Vegetation types & $\begin{array}{c}\text { Altitude (m } \\
\text { above sea level) }\end{array}$ \\
\hline \multirow[t]{7}{*}{ Mukomuko } & MM1 & $101^{0} 14$ '49.3" E; 02031'30.6" S & Oil palm plantations & 44 \\
\hline & MM2 & $101^{0} 08^{\prime} 54.0^{\prime \prime} \mathrm{E} ; 02^{0} 31^{\prime} 30.7^{\prime \prime} \mathrm{S}$ & Grassland & 20 \\
\hline & MM3 & $101^{0} 07^{\prime} 48.7^{\prime \prime} \mathrm{E} ; 02^{0} 28^{\prime} 52.4^{\prime \prime} \mathrm{S}$ & Paddy field & 21 \\
\hline & MM4 & $101^{\circ} 03^{\prime} 49.5^{\prime \prime} \mathrm{E} ; 02^{0} 29^{\prime} 26.8$ " S & Oil palm plantations & 20 \\
\hline & MM5 & $101^{0} 19^{\prime} 23.0^{\prime \prime} \mathrm{E} ; 02^{0} 37^{\prime} 55.6$ " S & Oil palm plantations & 93 \\
\hline & MM6 & $101^{0} 27^{\prime} 10.7^{\prime \prime} \mathrm{E} ; 02^{0} 55^{\prime} 56.4^{\prime \prime} \mathrm{S}$ & Oil palm plantations & 18 \\
\hline & MM7 & $101^{0} 33^{\prime} 27.6^{\prime \prime} \mathrm{E} ; 03^{0} 00^{\prime} 32.7^{\prime \prime} \mathrm{S}$ & Oil palm plantations & 88 \\
\hline \multirow[t]{7}{*}{ North Bengkulu } & NB1 & $102^{0} 13^{\prime} 34.0^{\prime \prime} \mathrm{E} ; 03^{0} 28^{\prime} 40.5^{\prime \prime} \mathrm{S}$ & Rubber plantations & 175 \\
\hline & NB2 & $102^{0} 03^{\prime} 39.0^{\prime \prime} \mathrm{E} ; 03^{0} 32^{\prime} 07.00^{\prime \prime} \mathrm{S}$ & Mango plantations & 20 \\
\hline & NB3 & $101^{0} 48^{\prime} 32.2^{\prime \prime} \mathrm{E} ; 03^{0} 15^{\prime} 8.99 " \mathrm{~S}$ & Rubber plantations & 99 \\
\hline & NB4 & $101^{0} 37^{\prime} 15.0^{\prime \prime} \mathrm{E} ; 03^{0} 14^{\prime} 23.0^{\prime \prime} \mathrm{S}$ & Oil palm plantations & 20 \\
\hline & NB5 & $101^{0} 50 ' 20.5^{\prime \prime} \mathrm{E} ; 03^{0} 09^{\prime} 41.7^{\prime \prime} \mathrm{S}$ & Rubber plantations & 80 \\
\hline & NB6 & $101^{0} 43^{\prime} 31.2^{\prime \prime} \mathrm{E} ; 03^{0} 18^{\prime} 57.1$ " S & Shrublands & 20 \\
\hline & NB7 & $102^{0} 01 ' 30.9^{\prime \prime} \mathrm{E} ; 03^{0} 19^{\prime} 19.9$ " S & Oil palm plantations & 88 \\
\hline \multirow[t]{7}{*}{ Central Bengkulu } & CB1 & $102^{0} 30^{\prime} 35.5^{\prime \prime} \mathrm{E} ; 03^{0} 42^{\prime} 20.9^{\prime \prime} \mathrm{S}$ & Rubber plantations & 196 \\
\hline & $\mathrm{CB} 2$ & $102^{0} 26^{\prime} 12.0^{\prime \prime} \mathrm{E} ; 03^{0} 50^{\prime} 14.9^{\prime \prime} \mathrm{S}$ & Rubber plantations & 201 \\
\hline & CB3 & $102^{0} 23^{\prime} 23.9^{\prime \prime} \mathrm{E} ; 03^{0} 50^{\prime} 19.6$ " S & Oil palm plantations & 21 \\
\hline & CB4 & $102^{0} 20^{\prime} 23.3^{\prime \prime} \mathrm{E} ; 03^{0} 46^{\prime} 50.8^{\prime \prime} \mathrm{S}$ & Oil palm plantations & 21 \\
\hline & CB5 & $102^{0} 28^{\prime} 22.4^{\prime \prime} \mathrm{E} ; 03^{0} 38^{\prime} 05.2^{\prime \prime} \mathrm{S}$ & Oil palm plantations & 105 \\
\hline & CB6 & $102^{0} 18^{\prime} 58.6 " \mathrm{E} ; 03^{0} 41^{\prime} 54.5 " \mathrm{~S}$ & Oil palm plantations & 50 \\
\hline & CB7 & $102^{0} 15^{\prime} 48.5^{\prime \prime} \mathrm{E} ; 03^{0} 43^{\prime} 49.8$ " S & Paddy field & 50 \\
\hline
\end{tabular}

Note: Site codes were taken from Figure 1. 
Table 2. Land characteristics in the study region

\begin{tabular}{|c|c|c|c|c|c|c|}
\hline \multirow{2}{*}{ Land characteristics } & \multicolumn{2}{|c|}{ Oil palm sites } & \multicolumn{2}{|c|}{ Rubber sites } & \multicolumn{2}{|c|}{ Others* } \\
\hline & $0-10 \mathrm{~cm}$ & $10-20 \mathrm{~cm}$ & $0-10 \mathrm{~cm}$ & $10-20 \mathrm{~cm}$ & $0-10 \mathrm{~cm}$ & $10-20 \mathrm{~cm}$ \\
\hline Sand (\%) & $38.91-85.24$ & $32.51-87.57$ & $39.23-72.14$ & $27.56-76.96$ & $53.23-87.96$ & $32.49-74.96$ \\
\hline Silt $(\%)$ & $7.81-35.57$ & $7.86-31.88$ & $12.37-23.58$ & $12.26-36.23$ & $7.62-29.98$ & $15.47-36.01$ \\
\hline Clay $(\%)$ & $4.63-25.97$ & $4.56-35.61$ & $11.74-38.80$ & $11.06-40.01$ & $4.42-22.76$ & $9.58-42.69$ \\
\hline Texture class & $\begin{array}{l}\text { Loam-loamy } \\
\text { sand }\end{array}$ & $\begin{array}{l}\text { Clay loam-loamy } \\
\text { sand }\end{array}$ & $\begin{array}{l}\text { Clay loam- } \\
\text { sandy loam }\end{array}$ & $\begin{array}{l}\text { Clay loam- } \\
\text { sandy loam }\end{array}$ & $\begin{array}{l}\text { Loam-loamy } \\
\text { sand }\end{array}$ & $\begin{array}{l}\text { Clay-sandy } \\
\text { loam }\end{array}$ \\
\hline Bulk density (g cm-3) & $0.24-1.38$ & $0.47-1.27$ & $0.81-1.22$ & $0.87-1.36$ & $0.19-1.35$ & $0.25-1.32$ \\
\hline Particle density ( $\mathrm{g} \mathrm{cm}-3)$ & $1.80-2.53$ & $1.45-2.63$ & $2.03-2.79$ & $1.84-2.25$ & $0.89-2.58$ & $1.04-2.47$ \\
\hline Total porosity $(\%)$ & $45.45-87.56$ & $26.21-73.45$ & $51.08-70.97$ & $28.95-52.72$ & $27.03-78.67$ & $46.56-76.00$ \\
\hline Altitude ( $\mathrm{m}$ above sea level) & $20-105$ & & $80-201$ & & $20-50$ & \\
\hline
\end{tabular}

Note: Other sites include shrubs, mango, paddy field, and grass.

\section{Data analysis}

The diversity of SOC and water availability was analyzed using a grouped frequency distribution technique with an unequal number of samples for each vegetation type. Discrete data of SOC and available water content were grouped into 10-to-20 classes when forming relative frequency distributions (Snedecor and Cochran 1980) to give a general idea of the curve shapes of the distribution and to provide the descriptive summary statistics of both variables under different vegetation types. The relation between soil organic carbon and available water contents for all vegetation types was determined using the regression analysis.

\section{RESULTS AND DISCUSSION}

\section{Soil organic carbon and available water under different vegetation types}

Results presented in Table 3 showed that SOC contents of $3.0 \%$ or more were found more frequently at the uppermost $0-10 \mathrm{~cm}$ compared to the $10-20 \mathrm{~cm}$ depths for all vegetation types. Soil C content intervals of 3.0-6.0\% appeared most frequently, or about $80 \%$ of occurrence in the $0-10$ and $10-20 \mathrm{~cm}$ layers of rubber sites. SOC contents of more than $6.0 \%$ were found most frequently at the $0-10$ cm depth of non-plantation areas such as shrubs, paddy fields, and mango. The highest SOC contents were $39.94 \%$ at the $0-10 \mathrm{~cm}$ and $17.51 \%$ at the $10-20 \mathrm{~cm}$ soil depths, respectively, of the lowland paddy field in Central Bengkulu Regency (Site CB7). On the other hand, the SOC content of less than $2.0 \%$ was recorded at the $10-20 \mathrm{~cm}$ layers of grassland oil palm sites (MM2, MM7, NB4, and NB5).

Oil palm plantations occupied a wide range of lowland areas at 20 to $105 \mathrm{~m}$ above sea level and mainly consisted of mineral soils with the SOC intervals of more than $3.0 \%$ at the upper and less than $3.0 \%$ at the lower layers. Similarly, trends of higher SOC content at the uppermost soil layers were also found under rubber plantations and other types of vegetation covers. The results presented in Table 3 indicated that the addition of SOC under all types of vegetation was more pronounced at the topsoil. The presence of SOC content of above $6.0 \%$ suggested that the addition of $\mathrm{C}$ stock in the study areas was higher than reported elsewhere. For example, Ajidirman (2006) reported that 18 years' worth of cultivating oil palm plantations after deforestation only increased SOC of about $0.09 \%$ at the $0-30 \mathrm{~cm}$ depth.

The frequency distributions for the occurrence of soil water content intervals at the field capacity condition are illustrated in Figure 2. Gravimetric soil water content at the field capacity condition for the $0.4-0.6 \mathrm{~g} \mathrm{~g}^{-1}$ interval appeared most frequently in all vegetation types compared to the intervals of less than $0.4 \mathrm{~g} \mathrm{~g}^{-1}$ and above $0.6 \mathrm{~g} \mathrm{~g}^{-1}$. The occurrence frequency of soil water content at the 0.4 $0.6 \mathrm{~g} \mathrm{~g}^{-1}$ interval was about $73 \%$ under oil palm and $60 \%$ under rubber and other types of vegetation, respectively, while those at the $<4.0 \mathrm{~g} \mathrm{~g}^{-1}$ were more frequently observed under shrubs. The results indicated that soils under mature oil palm trees held higher water content at the field capacity condition, or at the levels of about two days after a heavy rain event, compared to rubber plantations and other types of vegetation. The superiority of oil palm over rubber plantations in maintaining soil wetness was like our earlier report from different study sites that soils under mature oil palm were consistently wetter at a depth of $0-20 \mathrm{~cm}$ than those under rubber trees (Hermawan et al. 2019).

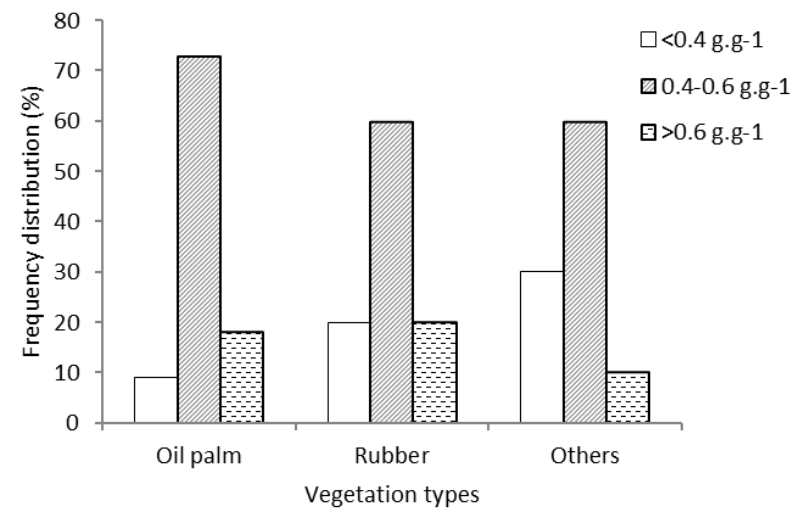

Figure 2. Frequency distribution of soil water content intervals ( $g$ $\left.\mathrm{g}^{-1}\right)$ at the field capacity condition under three vegetation types 
Table 3. Frequency distribution (\%) of soil-C intervals at $0-10$ and $10-20 \mathrm{~cm}$ depths as measured under three different vegetation types

\begin{tabular}{lcccccc}
\hline \multirow{2}{*}{\begin{tabular}{c} 
Soil carbon intervals \\
\cline { 2 - 7 }
\end{tabular}} & $\mathbf{0 - 1 0} \mathbf{~ c m}$ & $\mathbf{1 0 - 2 0} \mathbf{~ c m}$ & $\mathbf{0 - 1 0} \mathbf{~ c m}$ & $\mathbf{1 0 - 2 0} \mathbf{~ c m}$ & $\mathbf{0 - 1 0} \mathbf{~ c m}$ & Others* \\
\hline $0.5-2.0$ & 0 & 36 & 0 & 0 & 0 & $\mathbf{1 0 - 2 0} \mathbf{~ c m}$ \\
$2.0-3.0$ & 18 & 36 & 0 & 20 & 0 & 20 \\
$3.0-6.0$ & 37 & 10 & 80 & 80 & 20 & 20 \\
$>6.0$ & 45 & 18 & 20 & 0 & 80 & 40 \\
Number of samples & 11 & 11 & 5 & 5 & 5 & 5 \\
\hline
\end{tabular}

Note: Shrublands, mango plantation, paddy field, and grassland

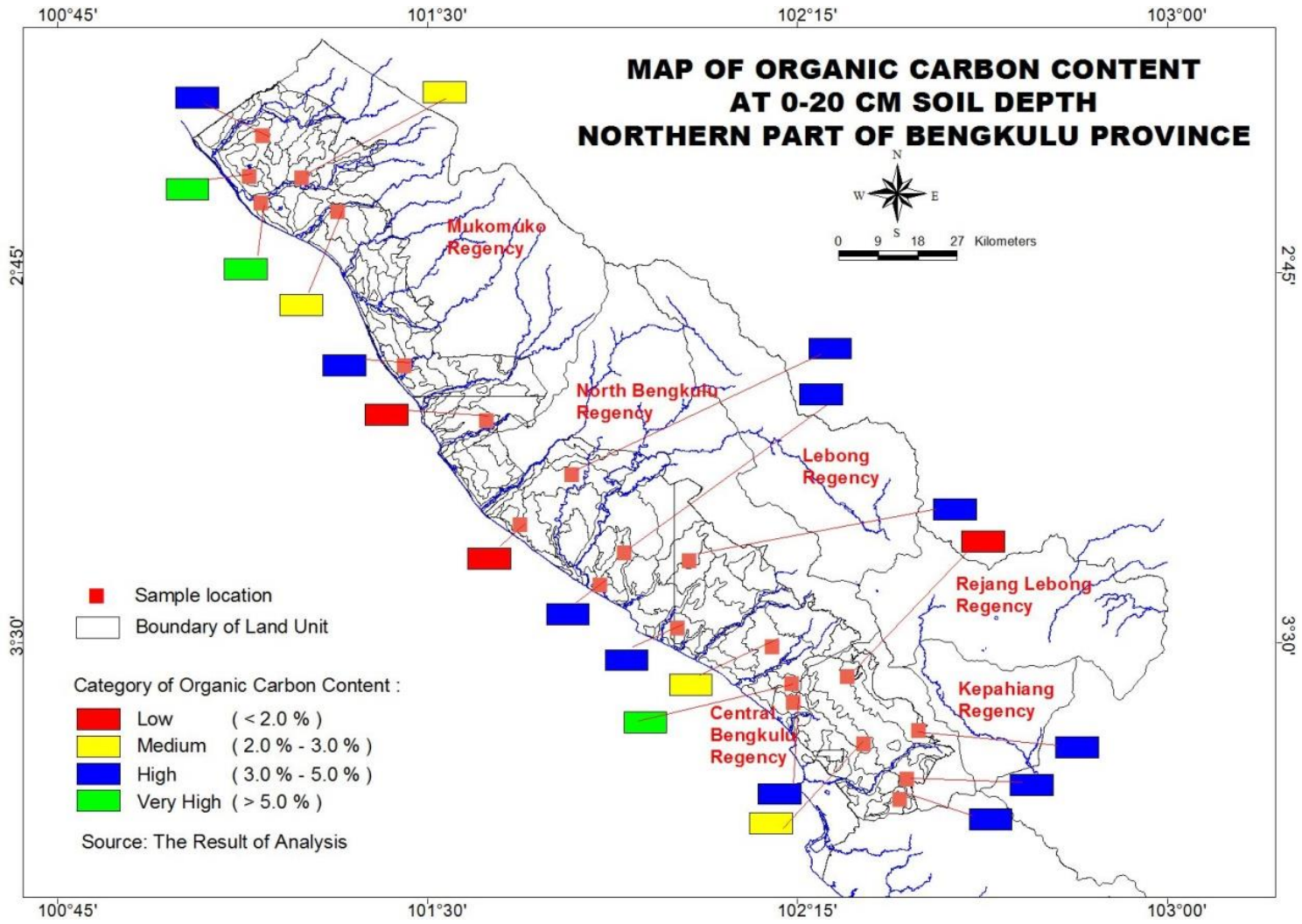

Figure 3. Spatial distributions of soil organic carbon at 0-10 and 10-20 cm layers in the northern part of Bengkulu Province
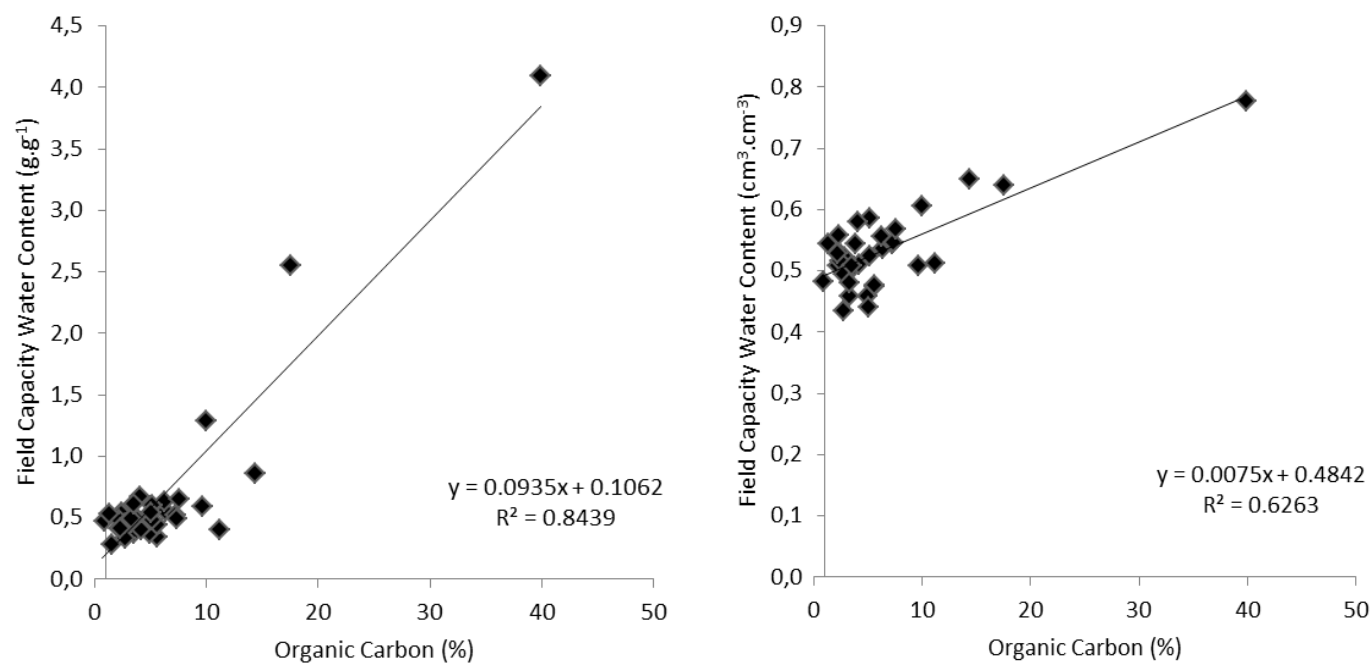

Figure 4. Models relating the gravimetric (left) and volumetric field capacity water content (right) to organic carbon of study soils 


\section{Spatial diversity of Soil Organic Carbon (SOC)}

Spatial diversity of SOC content intervals in the northern parts of Bengkulu Province is presented visually in Figure 3. About a half of soil sampling sites in the current study had high SOC content at an interval of 3.0$5.0 \%$ as measured at the $0-20 \mathrm{~cm}$ depth. The spatial distributions of SOC intervals found in this study represented soil fertility conditions in most parts of agricultural land in Bengkulu Region. The high content of $3.0-5.0 \%$ and medium level of $2.0-3.0 \%$ SOC were measured in three and four sites, or in about $14 \%$ and $18 \%$ of total occurrence, respectively. Low SOC of less than $2.0 \%$, on the other hand, was observed either in the coastal area of the oil palm plantation or under the oil palm trees and grass towards the border of protected forest land.

\section{Models to predict soil water from organic carbon}

Figure 4 presents two regression models that can be used to predict the availability of soil water content, both in the gravimetric and volumetric basis, from the diversity of SOC in the field. Organic carbon content of study soils had a better relation to the gravimetric rather than to the volumetric water content as indicated by a correlation coefficient of about $20 \%$ higher for the gravimetry. The SOC variations in the gravimetric model explained about $84 \%$ of the soil water content in comparison to the volumetric model of only $63 \%$. The slope for the gravimetric equation was about ten times higher than for the volumetric water content, indicating greater responses of the first to the variations in SOC content. An increase in $1 \%$ SOC content would improve the gravimetric and volumetric soil water contents at the field capacity conditions by $0.094 \mathrm{~g} \mathrm{~g}^{-1}$ and $0.008 \mathrm{~cm}^{3} \mathrm{~cm}^{-3}$, respectively.

The models presented in Figure 4 suggest that the best relations between SOC and water content at the field capacity condition were found at soils with SOC content higher than $10 \%$. This is because water absorption by soils with lower carbon content was also influenced by noncarbon factors such as the particle-size distribution of mineral compounds, as well as shapes and sizes of soil structure. Clay-dominant soils preserved more water compared to sandy soils, while the fine granular structure could transmit and absorb more rainfall water than the coarse blocky structure. When SOC content reached 10\% or higher, the carbon-water relations seemed to be very strong; therefore, the effects of soil texture and structure were probably negligible in this study. The presence of $\mathrm{OM}$ in soils would maintain high gravimetric water content as much as four times higher than the mass of organic fraction itself.

\section{Discussion}

The results of the current study suggested that SOC and water content at the field capacity condition varied across the study sites with different types of vegetation cover. The findings agreed with those reported elsewhere that spatial diversity of measured SOC was strongly affected by vegetation types, hydrology, and buried organic material in the soil profile (Elberling et al. 2004). In the current study, oil palm plantations stored more organic carbon at the 0-10 $\mathrm{cm}$ soil depth compared to rubber plantations, while low SOC content was found at the lower soil layers under all types of vegetation. However, differences in SOC under various land units as found in the current study were not solely related to vegetation types but also to other environmental characteristics such as land typology. The SOC content of greater than $10 \%$ mainly appeared in the lowland areas of under $50 \mathrm{~m}$ above sea level, which likely used to be coastal basins filled with an accumulation of organic materials. An oil palm site in Mukomuko (MM4) and a paddy field in Central Bengkulu (CB7) were two sites in lowland areas containing very high $\mathrm{OM}$ content.

The effects of vegetation types on the SOC stock in the soil could be explained from the aboveground and belowground characteristics of the plant. Leaves of mature oil palm trees were periodically pruned and piled, resulted in a large amount of aboveground organic litters up to 30 times higher than the amount for other plants (Ramos et al. 2018). In the current study, decomposition of aboveground litters in the oil palm plantations could be the reason for higher SOC content than under rubber and other vegetation types. Below ground biomass of oil palm trees might also contribute to the higher SOC than other plants due to the amount and architecture of roots, especially at the points close to the palm trunk (Frazão et al. 2014). Two paddy field sites also had an SOC content of greater than 10\%, particularly at the top $10 \mathrm{~cm}$ layer, probably due to the returning of rice straw-mulch to the soil with tillage operations (Adhikari et al. 2017).

The model developed in this study may be useful to evaluate the spatial and temporal distributions of the potential drought effects on crop growth and yields during the dry seasons, as well as to promote innovative technologies in crop performance improvements under water stress conditions. Mau et al. (2019), for example, reported six F1 hybrids of drought-tolerance genotypes of sweet potatoes that can be highly productive in both normal and water-stressed conditions. On the other hand, problems related to soil water stress could be overcome by improving the SOC storage in the soil through the establishment of the annual plant population. Study by Borchard et al. (2019) showed that mature rubber plantations increased the SOC storage to the level comparable to the secondary forests, although the increase was lower compared to mature oil palm, as found in the current study. Similarly, Frazão et al. (2013) reported there had been up to an $18 \%$ increase in SOC content under oil palm plantations compared to native forests.

It can be concluded that the diversity of SOC and water content of soil could be evaluated from the spatial distributions of vegetation types. Soils covered by crops with periodically returned biomass and well-distributed root systems had greater amounts of aboveground and belowground organic materials as the source of SOC. Since SOC had a strong relation with soil wetness, these characteristics of vegetation would also be beneficial in improving the water-holding capacity of soils. 


\section{ACKNOWLEDGEMENTS}

This study was fully funded by the University Superior Research Program, the University of Bengkulu 2018 Fiscal Year, SP DIPA-042.01.2.4000977/2018, Contract number: 2345/UN30.15/LT/2018.

\section{REFERENCES}

Adhikari KR, Dahal KR, Chen Zueng-Sang, T Yih-Chi, LJihn-Sung 2017. Rice-wheat cropping system: tillage, mulch, and nitrogen effects on soil carbon sequestration and crop productivity. Paddy Water Environ 15: 699-710.

Ajidirman A. 2006. A study on soil organic carbon restoration in relation to soil physical fertility under oil palm vegetation. Jurnal Agronomi 10 (2). [Indonesian]

Barton L, Colmer TD. 2011. Granular wetting agents ameliorate water repellency in turfgrass of contrasting soil organic matter content. Plant Soil 348 (1/2): 411-424.

Borchard N, Bulusu M, Meyer N, Rodionov A, Herawati H, Blagodatsky S, Cadisch G, Welp G, Amelung W, Martius C. 2019. Deep soil carbon storage in tree-dominated land use systems in tropical lowlands of Kalimantan. Geoderma 354. DOI 10.1016/j.geoderma.2019.07.022. [Indonesian]

BPS. 2016. Bengkulu Province in Figures. Statistics of Bengkulu Province, Bengkulu City. [Indonesian]

Centre for Soil and Agroclimate Research. 1990. Land Unit and Soil Map of the Sungai Penuh Sheet, Sumatra. Centre for Soil and Agroclimate Research, Bogor.

Elberling B, Jakobsen BH, Berg P, Søndergaard J, Sigsgaard C. 2004 Influence of vegetation, temperature, and water content on soil carbon distribution and mineralization in four High Arctic Soils. Arct Antarct Alp Res 36 (4): 528-538.

Endriani. 2011. A study on compaction, erodibility and aggregate stability of Andisol affected by land-use changes in upper Batang Merao Watershed. Jurnal Hidrolitan 2 (1): 40-47. [Indonesian]

Frazão LA, Paustian K, Cerri CEP, Cerri CC. 2013. Soil carbon stocks and changes after oil palm introduction in the Brazilian Amazon. GCB Bioenergy 5: 384-390. DOI: 10.1111/j.1757-1707.2012.01196.x

Frazão LA, Paustian K, Cerri CEP, Cerri CC. 2014. Soil carbon stocks under oil palm plantations in Bahia State, Brazil. Biomass Bioenergy 62. DOI: 10.1016/j.biombioe.2014.01.031
Hermawan B, Rosanty Y, Susetyo, A. 1997. Soil structural degradation after two years of forest harvesting and shifting cultivation. Proceeding of National Seminar on Potential and Principle of Environmental Managements for Regional Development. Joint Work of UNIB-BAPEDAL, Bengkulu City.

Hermawan B, Suhartoyo H, Anandyawati S, Gonggo B, Agustian I. 2019. Spatial variability in soil water under adjacent mature oil palm and rubber plantations: application of a new dielectric method in evaluating soil water. Intl J Agric Technol 15 (2): 261-272.

Karyati S, Karmini S, Simangunsong G, Tamba J. 2018. The mixed cropping of Anthocephalus cadamba and Glycine max for rehabilitating sloping lands. Biodiversitas 19 (6): 2088-2095.

Klute A (ed). 1986. Methods of Soil Analysis. 2nd ed. Soil Sci Soc Am Inc. Publ., Madison.

Mau YS, Ndiwa ASS, Markus JER, Arsa IGBA. 2019. Agronomic performance and drought tolerance level of sweet potato hybrids grown in Kupang, East Nusa Tenggara, Indonesia. Biodiversitas 20 (8): 2187-2196

Mey D, Sartohadi J, Mardiatno D, Marfai MA. 2015. Prediction of soil organic carbon loss due to erosion in Girindulu Watersheds. J Degraded Mining Lands Manag 2 (3): 327-334.

Mujiono M, Harmantyo D, Indra TL, Rukmana IP, Nadia Z. 2017. Simulation of land-use change and effect on potential deforestation using Markov Chain - Cellular Automata. AIP Conf Proc 1862: 030177. DOI: 10.1063/1.4991281.

Pransiska Y, Triadiati T, Tjitrosoedirjo S, Hertel D, Kotowska MM. 2016. Forest conversion impacts on the fine and coarse root system, and soil organic matter in tropical lowlands of Sumatera (Indonesia). For Ecol Manag 379: 288-298.

Ramos HMN, Vasconcelos SS, Kato OR, Castellani DC. 2018. Aboveand belowground carbon stocks of two organic, agroforestry-based oil palm production systems in eastern Amazonia. Agrofor Syst 92 (2): 221-237. DOI: 10.1007/s10457-017-0131-4

Rusdiana O, Lubis RS. 2012. Pendugaan korelasi antara karakteristik tanah terhadap cadangan karbon (carbon stock) pada hutan sekunder. Jurnal Silvikultur Tropika 3 (1): 14-21. [Indonesian]

Saha R, Mishra VK. 2009. Effect of organic residue management on soil hydro-physical characteristics and rice yield in Eastern Himalayan Region, India. J Sustain Agric 33 (2): 161-176.

Snedecor GW, Cochran WG. 1980. Statistical Methods. $7^{\text {th }}$ ed. The Iowa State University Press, Iowa.

Supriyono. 2018. Critical land detection Watershed River Bengkulu and effect of coastal area using Geographic Information System. Sumatra J Disaster Geogr Geogr Educ 2 (1): 30-37. [Indonesian] 